\title{
PENGARUH KUALITAS PEMBIAYAAN TERHADAP EFEKTIVITAS PENDAPATAN (Studi Kasus di BMT Artha Barokah Yogyakarta 2012)
}

\author{
Amrizal Putra dan Ahmad Yunadi \\ Prodi Ekonomi Syari'ah STIA Alma Ata Yogyakarta \\ Email: mansurin_jokam@yahoo.co.id
}

\begin{abstract}
KJKS BMT is an institution that serves as an intermediary (Intermediary Institution) financial, KJKS BMT third -party funds to the public. Among them are mudharabah and Musharaka. The background of this research is that the prospects of the business, customer performance, and the ability to pay is a factor that is used to measure the effectiveness of customer revenue Artha Barokah BMT. This study was conducted to determine whether the business prospect, customer performance, and the ability to pay affect the revenues of the BMT Artha Barokah customers. Type of research is a field (field reserch) with documentation of data collection methods, because the data used in this study is secondary data obtained from the customer data is filled directly. The analytical tool used is multiple linear regression testing using classical linear regression aberration test and statistical tests .

Results of $t$ test analysis showed that each of the independent variables significantly affect the revenues of customers in BMT Artha Yogyakarta blessing. In the $F$ test shows that the performance of the independent variables and the ability of customers to pay a significant effect while the prospects do not significantly influence customers' budget revenues. The determinansi coefficient $\left(R^{2}\right)$ of 0.440 , which means that the budget revenue on customer BMT Artha Barokah able to be explained by the independent variables was $44.0 \%$ and the remaining $56.0 \%$ is influenced by other variables outside the model of this study
\end{abstract}

Keywords: BMT, Financing Quality, The Effectiveness of Income

\section{PENDAHULUAN}

Eksistensi lembaga keuangan khususnya sektor perbankan menempati posisi sangat strategis dalam menjembatani kebutuhan modal kerja dan investasi di sektor riil dengan pemilik dana. Dengan demikian, fungsi utama sektor perbankan dalam infranstruktur kebijakan makro ekonomi memang diarahkan dalam konteks bagaimana menjadikan uang efektif untuk meningkatkan nilai tambah ekonomi ( how to make money effective and efficient to increase economic value ) (Muhammad, 2005).

JESI

JURNAL EKONOMI

SYARIAH

INDONESIA

Banyak bank tidak memiliki strategi usaha yang fokus. Penyaluran kredit dilakukan serampangan tanpa melalui strategi segmentasi/distribusi dan diversifikasi yang jelas. Sementara itu, struktur dan kemampuan sumber dana pendukung ekspansi sangatlah lemah sehingga menimbulkan gap yang cukup besar. Lebih mengerikan lagi, ternyata banyak bank yang beroperasi dengan 
sistem dan prosedur operasi seadanya tanpa disertai mekanisme pengawasan yang memadai. Kurangnya perhatian terhadap aspek manajemen perbankan ini menyebabkan pengelolaan resiko menjadi terabaikan (Muhammad, 2005).

Pemicu utama kebangkrutan yang dialami oleh bank, terletak pada ketidakmampuan bank memenuhi kebutuhan likuiditasnya. Likuiditas pada perbankan syariah sebagian besar bergantung pada perolehan dana pihak ketiga (deposits) berupa invesment account maupun current account, yang akan disalurkan ke pembiayaan sesuai syariah seperti mudharabah, musyarakah, murabahah, salam, ishtisna, dan ijarah. Rasio likuiditas (liquidity ratio) disebut juga rasio modal kerja. Rasio ini digunakan untuk mengukur likuidnya sebuah bank, yaitu dengan membandingkan seluruh komponen aktiva lancar dengan komponen pasiva lancar. Rasio ini juga menunjukkan kemampuan bank untuk memenuhi kebutuhan transaksi pada saat nasabah melakukan penarikan. Jika sebuah bank tidak bisa memenuhi kebutuhan nasabah, berarti bank tersebut mengalami resiko likuiditas. Artinya bank tidak bisa memenuhi kewajiban atau sudah tidak mampu membiayai (Kasmir dan Jafkar, 2003). Besar kecilnya resiko likuiditas banyak ditentukan beberapa indikator yaitu (Arifin, 2006): Kecermatan perencanaan arus kas (cash flow) atau arus dana (fund flow) berdasarkan prediksi pembiayaan dan prediksi pertumbuhan dana, termasuk mencermati tingkat fluktualitas dana (volatility of funds), Ketepatan dalam mengatur struktur dana, termasuk kecukupan dana-dana non-PLS (profit and loss sharing), Ketersediaan asset yang siap dikonversikan menjadi kas, Kemampuan menciptakan akses kepasar antar bank atau sumber dana lainnya, termasuk fasilitas lender of last resort.

Baitul Maal Wa Tamwil (BMT) sebagai lembaga mikro syariah yang bersentuhan langsung dengan kehidupan masyarakat kecil diharapkan mampu menjalankan misinya dan dapat mengurangi ketergantungan masyarakat dan pedagang-pedagang kecil dari lembaga keuangan yang bukan syariah yang bunganya relatif tinggi (Arifin, 2006).

Berdasarkan latar belakang diatas penulis tertarik untuk melakukan penelitian dengan judul "Pengaruh Kualitas Pembiayaan Terhadap Efektifitas Pendapatan" studi kasus di BMT Artha Barokah Yogyakarta.

\section{METODOLOGI PENELITIAN}

Penelitian yang dilakukan berkaitan dengan studi dalam skripsi ini yaitu dengan menggunakan pendekatan kuantitatif. Artinya data yang diambil berasal dari lapangan secara langsung menggunakan kuesioner di analisis dengan metode kuantitatif, setelah itu hasil dari analisis di deskripsikan (Supardi, 2005). Penelitian ini dirancang dengan menggunakan pendekatan cross-sectional. Pendekatan cross-sectional, artinya dalam penelitian ini teknik pengumpulan datanya dilakukan dengan satu periode waktu tertentu, setiap subjek, studinya hanya satu kali pengamatan selama penelitian, maksudnya ketika memberikan kuesioner hanya satu kali saja dan tidak dilakukan perulangan (Husein, 2005). Kegiatan penelitian dilakukan di BMT Artha Barokah, Imogiri, Bantul, Yogyakarta. Subjek dalam penelitian ini adalah karyawan dan nasabah yang telah tercatat aktif sebagai anggota di BMT Artha Barokah. Sedang obyek penelitiannya adalah kualitas pembiayaan dan efektifitas pendapatan BMT Artha Barokah.

Populasi dan sampel merupakan subyek penelitian. Menurut Suharsimi mengatakan "Populasi adalah keseluruhan subyek penelitian".Sedangkan yang dimaksud sampel menurutnya: "Sebagai atau wakil populasi yang

Amrizal

Putra

JURNAL EKONOMI SYARIAH INDONESIA, Volume V, No.1 Juni 2015 
diteliti" (Suharsimi, 2002). Pada kegiatan penelitian ini subyek populasi adalah seluruh nasabah yang berjumlah 473 orang (Kasidi, 2013). Dengan demikian sampel yang diambil sebanyak 50 responden. Dasar pengambilan sampel tersebut sesuai yang dikemukakan oleh Suharsimi bahwa untuk sekedar patokan maka apabila subyeknya kurang dari 100, lebih baik diambil semua sehingga penelitiannya merupakan penelitian populasi. Selanjutnya jika jumlah subyeknya besar dapat diambil antara $10-15 \%$ atau $20-25 \%$ atau lebih (Suharsimi, 2002). Kegiatan penelitian dilakukan di BMT Artha Barokah, Imogiri, Bantul, Yogyakarta. Dan pelaksanaan kegiatan penelitian ini dilaksanakan pada bulan Juli 2013, lebih kurang dua bulan. Adapun pelaksanaan waktu ini digunakan agar data yang dibutuhkan dapat diperoleh sampai penelitian ini selesai.

\section{Variabel Penelitian}

Dalam penelitian ini, ada dua variabel penelitian:

Variabel bebas $(X)$ yaitu variabel yang nilainya tidak tergantung pada variabel lain, adapun menjadi variabel bebas dari penelitian ini adalah: Faktor dari Prospek Usaha (X1) yaitu faktor yang berkaitan dengan ketepatan usaha yang dipilih, faktor dari Kinerja (Performance) Nasabah (X2) yaitu faktor yang berkaitan dengan keberhasilan nasabah dalam menjalankan usaha, Faktor dari Kemampuan Membayar (X3) yaitu faktor yang berkaitan dengan ketepatan membayar.

Variabel Terikat $(\mathrm{Y})$ yaitu variabel yang nilainya tergantung pada variabel lain. Adapun yang menjadi variabel terikat adalah anggaran pendapatan yang diperoleh BMT Artha Barokah Yogyakarta.

Pengukuran Variabel Penelitian. Untuk memudahkan dalam menganalisis data maka variabel-variabel yang digunakan adalah model skala 5 tingkat yang memungkinkan koesioner dapat menjawab pertanyaan dari setiap butir yang didalamnya menguraikan 3 Pengaruh kualitas pembiayaan terhadap efektifitas pendapatan dengan bentuk penilaian sebagai berikut:

\begin{tabular}{lc}
\hline $\begin{array}{c}\text { Skala penilaian faktor-faktor pembiayaan dan } \\
\text { dampak bagi kepercayaan nasabah }\end{array}$ & skor \\
\hline (1) = Sangat Setuju (ST) & 5 \\
(2) = Setuju (S) & 4 \\
(3) = Netral (N) & 3 \\
(4) = Tidak Setuju (TS) & 2 \\
(5) = Sangat Tidak Setuju (STS) & 1 \\
\hline
\end{tabular}

\section{Teknik dan Instrumen Pengumpulan Data}

Dalam data kuantitatif data yang dikumpulkan seharusnya harus akurat, up to date, komprehensif dan relevan bagi persoalan atau permasalahan yang diteliti. Penggunaan data primer lebih diutamakan daripada penggunaan data sekunder Teknik pengumpulan data adalah alat yang digunakan untuk mengumpulkan data (Dajan, 1986).

Jenis-jenis data tersebut dapat dikelompokan sebagai berikut :

Pengaruh

Kualitas

\section{Data primer}

Yaitu data yang diperoleh peneliti dari sumber pertama baik individu maupun perseorangan, seperti hasil wawancara atau pengisian koesioner (Umar, 2000). 


\section{Data sekunder}

Yaitu data yang telah diolah lebih lanjut dan disajikan baik oleh pihak pengumpul data primer maupun pihak lain.

Penulis akan melakukan penelitian ini dengan menggunakan data primer dengan langsung melakukan observasi penelitian ke lembaga keuangan syariah tersebut dalam hal ini adalah BMT Artha Barokah.

\section{Teknik Pengumpulan Data}

Dalam penelitian ini peneliti menggunakan teknik pengumpulan data primer yang didapatkan melalui teknik-teknik sebagai berikut:

\section{Observasi (Pengamatan Langsung)}

Yaitu dengan cara melakukan pengamatan secara langsung dilokasi untuk memperoleh data yang diperlukan. Dalam penelitian ini penulis akan melakukan pengamatan secara langsung pada BMT Artha Barokah

\section{Dokumentasi}

Bukti-bukti dan dokumen-dokumen yang berkaitan dengan objek penelitian yang diperlukan penulis untuk dijadikan bahan dalam pembuatan skripsi. Adapun dokumen-dokumen yang akan digunakan oleh penulis antara lain, dokumen mengenai dokumen-dokumen yang menggambar sejarah BMT Artha Barokah, dokumen yang menerangkan struktur organisasi dan deskripsi kerja pada BMT Artha BArokah itu sendiri.

\section{HASIL PEMBAHASAN}

\section{Analisis dan Pembahasan}

\section{Uji Validitas}

Pengujian validitas dilakukan dengan menggunakan SPSS 16.0 dengan kriteria sebagai berikut:

Jika rhitung positif dan rhitung $>$ rtabel maka pernyataan tersebut valid. Jika rhitung negatif dan rhitung< rtabel maka pernyataan tersebut tidak valid. rhitung dapat dilihat pada kolom corrected item-total correlation.

Pada tahap survey, kuesioner berisikan 16 butir pernyataan yang menyangkut variabel bebas yaitu faktor prospek usaha, faktor kinerja nasabah, dan faktor kemampuan membayar; dan variabel terikat yaitu anggaran pendapatan pada BMT Artha Barokah Yogyakarta.

\section{Amrizal \\ Putra}


Tabel 1. Validitas Tiap Pernyataan

\begin{tabular}{cccc}
\hline & $\begin{array}{c}\text { Corrected item-total correlation } \\
\text { (r hitung) }\end{array}$ & r table & Validitas \\
\hline Pernyataan 1 & 0.793 & 0,248 & Valid \\
Pernyataan 2 & 0.869 & 0,248 & Valid \\
Pernyataan 3 & 0.891 & 0,248 & Valid \\
Pernyataan 4 & 0.667 & 0,248 & Valid \\
Pernyataan 5 & 0.766 & 0,248 & Valid \\
Pernyataan 6 & 0.853 & 0,248 & Valid \\
Pernyataan 7 & 0.873 & 0,248 & Valid \\
Pernyataan 8 & 0.733 & 0,248 & Valid \\
Pernyataan 9 & 0.888 & 0,248 & Valid \\
Pernyataan 10 & 0.885 & 0,248 & Valid \\
Pernyataan 11 & 0.884 & 0,248 & Valid \\
Pernyataan 12 & 0.948 & 0,248 & Valid \\
Pernyataan 13 & 0.737 & 0,248 & Valid \\
Pernyataan 14 & 0.945 & 0,248 & Valid \\
Pernyataan 15 & 0.918 & 0,248 & Valid \\
Pernyataan 16 & 0.723 & 0,248 & Valid \\
\hline
\end{tabular}

Sumber: Hasil pengolahan data (kuesioner) dengan SPSS 16.0

Kolom corrected item-total correlation menunjukkan kolerasi antara skor item dengan skor total item yang dapat digunakan untuk menguji validitas instrument. Pada signifikan 5\%, rtabel sebesar 0,248 pada hasil dapat dilihat bahwa nilai corrected item-total correlation (rhitung) semuanya lebih besar dari nilai rtabelsehingga dapat disimpulkan bahwa ke-16 pernyataan tersebut valid.

\section{Uji Reliabilitas}

Pengujian dilakukan dengan menggunakan SPSS versi 16.0.butir pernyataan yang sudah dinyatakan valid dalam uji validitas ditentukan reliabilitasnya dengan kriteria sebagai berikut: Jika ralpha positif dan > rtabel maka reliabel dan Jika ralpha negatif dan < rtabel maka tidak reliabel.

Suatu instrument pernyataaan dikatakan reliabel apabila memiliki cronbach alpha $=0,60$, jika instrument pernyataan $<0,60$ maka instrument pernyataan tersebut tidak baik.

Tabel 2. Reliabilitas Tiap Pernyataan

\begin{tabular}{cc}
\hline Ralpha & Rtabel \\
\hline 0,688 & 0,248 \\
\hline
\end{tabular}

Sumber: Hasil pengolahan data (kuesioner) dengan SPSS 14.0, 2010

Pada 16 butir pernyataan yang diberikan dengan tingkat signifikan $5 \%$ dan ralpha $=0,688$;ini berarti ralpha $>$ rtabel yaitu 0,248 . Sehingga dapat dinyatakan bahwa kuesioner tersebut telah reliabel dan dapat disebarluaskan kepada responden sebagai instrument dalam penelitian ini.

Pengaruh Kualitas

\section{Analisis Deskriptif Responden Pada BMT Artha Barokah Yogyakarta}

\section{Deskriptif Responden}

Instrument yang digunakan dalam penelitian ini adalah kuesioner.Dari kuesioner tersebut diperoleh gambaran umum mengenai karakteristik responden. 
Karakteristik responden dalam penelitian ini antara lain berdasarkan nama, alamat, umur, jenis kelamin, agama, pendidikan, pekerjaan, dan penghasilan yang merupakan nasabah pada BMT Artha Barokah Yogyakarta.

\section{Karakteristik Berdasarkan Umur}

Berikut ini tabel umur nasabah yang menjadi responden berdasarkan hasil penelitian melalui kuesioner adalah sebagai berikut:

Tabel 3. Karakteristik Berdasarkan Umur

\begin{tabular}{ccc}
\hline & Jumlah Responden & Presentasi \\
\hline $0-20$ tahun & 0 & $0 \%$ \\
$21-40$ tahun & 23 & $46 \%$ \\
$41-60$ tahun & 27 & $54 \%$ \\
\hline Jumlah & $\mathbf{5 0}$ & $\mathbf{1 0 0} \%$ \\
\hline Sumber: Hasil pengolahan data (kuesioner) dengan SPSS 14.0, 2010
\end{tabular}

Sumber: Hasil pengolahan data (kuesioner) dengan SPSS 14.0, 2010

\section{Karakteristik berdasarkan jenis kelamin}

Berikut ini tabel jenis kelamin nasabah yang menjadi responden berdasarkan hasil penelitian melalui kuesioner adalah sebagai berikut:

Tabel 4. Karakteristik Berdasarkan Jenis Kelamin

\begin{tabular}{ccc}
\hline Jenis Kelamin & Jumlah Responden & Presentasi \\
\hline Laki-laki & 13 & $26 \%$ \\
Perempuan & 37 & $74 \%$ \\
\hline Jumlah & $\mathbf{5 0}$ & $\mathbf{1 0 0} \%$ \\
\hline
\end{tabular}

Sumber: Hasil pengolahan data (kuesioner) dengan SPSS 14.0.

\section{Karakteristik berdasarkan agama}

Berikut ini tabel agama nasabah yang menjadi responden berdasarkan hasil penelitian melalui kuesioner adalah sebagai berikut:

Tabel 5. Karakteristik Berdasarkan Agama

\begin{tabular}{ccc}
\hline & Jumlah responden & Presentasi \\
\hline Islam & 50 & $100 \%$ \\
Non-islam & 0 & $0 \%$ \\
\hline Jumlah & $\mathbf{5 0}$ & $\mathbf{1 0 0} \%$ \\
\hline
\end{tabular}

Sumber: Hasil pengolahan data (kuesioner) dengan SPSS 14.0.

\section{Karakteristik berdasarkan pendidikan}

Berikut ini tabel pendidikan nasabah yang menjadi responden berdasarkan hasil penelitian melalui kuesioner adalah sebagai berikut:

Tabel 6. Karakteristik Berdasarkan Pendidikan

\begin{tabular}{ccc}
\hline & Jumlah Responden & Presentasi \\
\hline SMP & 22 & $44 \%$ \\
SMA & 23 & $46 \%$ \\
Diploma & 1 & $2 \%$ \\
Sarjana & 4 & $8 \%$ \\
\hline Jumlah & $\mathbf{5 0}$ & $\mathbf{1 0 0} \%$ \\
\hline
\end{tabular}

Sumber: Hasil pengolahan data (kuesioner) dengan SPSS 14.0

Amrizal

Putra

JURNAL EKONOMI SYARIAH INDONESIA, Volume V, No.1 Juni 2015 


\section{Karakteristik Berdasarkan Pekerjaan}

Berikut ini tabel pekerjaan nasabah yang menjadi responden berdasarkan hasil penelitian melalui kuesioner adalah sebagai berikut:

Tabel 7. Karakteristik Berdasarkan Pekerjaan

\begin{tabular}{ccc}
\hline & Jumlah Responden & Presentasi \\
\hline Buruh & 8 & $16 \%$ \\
Tani & 1 & $2 \%$ \\
Swasta & 41 & $82 \%$ \\
Pegawai negeri & 0 & $100 \%$ \\
\hline Jumlah & $\mathbf{5 0}$ & $\mathbf{1 0 0} \%$ \\
\hline
\end{tabular}

Sumber: Hasil pengolahan data (kuesioner) dengan SPSS 14.0.

\section{Karakteristik Berdasarkan Penghasilan}

Berikut ini tabel penghasilan nasabah yang menjadi responden berdasarkan hasil penelitian melalui kuesioner adalah sebagai berikut:

Tabel 8. Karakteristik Berdasarkan Penghasilan

\begin{tabular}{|c|c|c|}
\hline Penghasilan & Jumlah Responden & Presentasi \\
\hline$\geq \operatorname{Rp} 100.000$ & 38 & $76 \%$ \\
\hline$\geq \operatorname{Rp} 1.000 .000$ & 12 & $24 \%$ \\
\hline$\geq \operatorname{Rp} 5.000 .000$ & 0 & $0 \%$ \\
\hline Jumlah & 50 & $100 \%$ \\
\hline
\end{tabular}

Sumber: Hasil pengolahan data (kuesioner) dengan SPSS 14.0.

\section{Deskriptif variabel}

Berikut ini adalah penjelasan secara deskriptif presentase hasil penelitian setiap variabel customer focus dengan tanggapan responden sebagai berikut:

Sangat Setuju (SS) diberi skor 5

Setuju (S)

Netral (N)

Tidak Setuju (TS)

diberi skor 4

Sangat Tidak Setuju (STS)

diberi skor 3

diberi skor 2

diberi skor 1

\section{Faktor Prospek Usaha sebagai Variabel X1}

Faktor Prospek Usaha merupakan faktor yang berkaitan dengan peluang usaha demi memenuhi kebutuhan hidupnya juga untuk mendapat keuntungan atau profit. Indikatornya terdiri dari Usaha yang dirintis, Tempat usaha, Keuntungan langsung dan Barang yang dijual. Tanggapan dari nasabah BMT Artha Barokah terhadap faktor Prospek usaha adalah sebagai berikut:

Tabel 9. Distribusi Pendapat Responden Terhadap Prospek Usaha (X1)

Pengaruh

Kualitas

\begin{tabular}{|c|c|c|c|c|c|c|c|c|c|c|c|c|}
\hline \multirow[t]{2}{*}{ BUTIR } & \multicolumn{2}{|c|}{$\begin{array}{c}\text { Sangat Tidak } \\
\text { Setuju }\end{array}$} & \multicolumn{2}{|c|}{$\begin{array}{l}\text { Tidak } \\
\text { Setuju }\end{array}$} & \multicolumn{2}{|c|}{ Netral } & \multicolumn{2}{|c|}{ Setuju } & \multicolumn{2}{|c|}{$\begin{array}{l}\text { Sangat } \\
\text { Setuju }\end{array}$} & \multirow{2}{*}{$\begin{array}{c}\text { Total } \\
\text { F } \\
\text { F }\end{array}$} & \multirow{2}{*}{$\begin{array}{c}\text { Total } \\
\% \\
\% \\
\end{array}$} \\
\hline & $\mathrm{F}$ & $\%$ & $\mathrm{~F}$ & $\%$ & $\mathrm{~F}$ & $\%$ & $\mathrm{~F}$ & $\%$ & $\mathrm{~F}$ & $\%$ & & \\
\hline 1 & 0 & 0 & 0 & 0 & 0 & 0 & 34 & 68 & 16 & 32 & 50 & 100 \\
\hline 2 & 0 & 0 & 1 & 2 & 5 & 10 & 36 & 72 & 8 & 16 & 50 & 100 \\
\hline 3 & 0 & 0 & 2 & 4 & 11 & 22 & 31 & 62 & 6 & 12 & 50 & 100 \\
\hline 4 & 0 & 0 & 0 & 0 & 8 & 16 & 37 & 74 & 5 & 10 & 50 & 100 \\
\hline
\end{tabular}


Berdasarkan tabel 9 dapat dilihat bahwa dari pernyataan Usaha yang dirintis, tidak ada responden $(0 \%)$ yang menyatakan sangat tidak setuju, tidak ada responden $(0 \%)$ menyatakan tidak setuju, tidak ada responden $(0 \%)$ menyatakan Netral, 34 responden (68\%) menyatakan setuju, dan 16 responden (32\%) menyatakan sangat setuju. Dari pernyataan Tempat usaha, tidak ada responden $(0 \%)$ yang menyatakan sangat tidak setuju, 1 responden $(2 \%)$ menyatakan tidak setuju, 5 responden $(10 \%)$ menyatakan Netral, 36 responden $(72 \%)$ menyatakan setuju, dan 8 responden $(16 \%)$ menyatakan sangat setuju. Dari pernyataan Keuntungan yang diterima langsung, tidak ada responden $(0 \%)$ yang menyatakan sangat tidak setuju, 2 responden $(4 \%)$ menyatakan tidak setuju, 11 responden (22\%) menyatakan Netral, 31 responden $(62 \%)$ menyatakan setuju, dan 6 responden (12\%) menyatakan sangat setuju. Dari pernyataan Barang yang dijual, tidak ada responden $(0 \%)$ yang menyatakan sangat tidak setuju, Tidak ada responden $(0 \%)$ menyatakan tidak setuju, 8 responden (16\%) menyatakan Netral, 37 responden $(64 \%)$ menyatakan setuju, dan 5 responden (10\%) menyatakan sangat setuju.

\section{Faktor Kinerja Nasabah sebagai Variable X2}

Faktor kinerja nasabah merupakan faktor-faktor yang berkaitan dengan hasil kerja yang dicapai nasabah dalam melaksanakan tugasnya sesuai dengan tanggug jawab yang diberikan kepadanya. Indikatornya terdiri dari Tidak bosan menjalankan usaha, Tanggap dengan peluang usaha, Pengelolaan pendapatan usaha dan mengahadapi resiko pasar. Tanggapan dari nasabah BMT Artha Barokah Yogyakarta terhadap faktor kinerja nasabah adalah sebagai berikut:

Tabel 10. Distribusi Pendapat Responden Terhadap Kinerja Nasabah (X2)

\begin{tabular}{cccccccccccccc}
\hline \multirow{2}{*}{ BUTIR } & $\begin{array}{c}\text { Sangat Tidak } \\
\text { Setuju }\end{array}$ & $\begin{array}{c}\text { Tidak } \\
\text { Setuju }\end{array}$ & \multirow{2}{*}{ Netral } & Setuju & $\begin{array}{c}\text { Sangat } \\
\text { Setuju }\end{array}$ & $\begin{array}{c}\text { Total } \\
\text { F }\end{array}$ & $\begin{array}{c}\text { Total } \\
\%\end{array}$ \\
\cline { 2 - 13 } & F & $\%$ & F & $\%$ & F & $\%$ & F & $\%$ & F & $\%$ & F & $\%$ \\
\hline 1 & 0 & 0 & 1 & 2 & 0 & 0 & 31 & 62 & 18 & 36 & 50 & 100 \\
2 & 0 & 0 & 1 & 2 & 6 & 12 & 34 & 68 & 9 & 18 & 50 & 100 \\
3 & 0 & 0 & 0 & 0 & 8 & 16 & 32 & 64 & 10 & 20 & 50 & 100 \\
4 & 0 & 0 & 0 & 0 & 11 & 22 & 34 & 68 & 5 & 10 & 50 & 100 \\
\hline
\end{tabular}

Berdasarkan tabel 10 dapat dilihat bahwa dari pernyataan Tidak bosan menjalani usaha, tidak ada responden $(0 \%)$ yang menyatakan sangat tidak setuju, 1 responden (2\%) menyatakan tidak setuju, tidak ada responden $(0 \%)$ menyatakan netral, 31 responden (62\%) menyatakan setuju, dan 18 responden $(36 \%)$ menyatakan sangat setuju. Dari pernyataan tanggap peluang usaha, tidak ada responden $(0 \%)$ yang menyatakan sangat tidak setuju, 1 responden $(2 \%)$ menyatakan tidak setuju, 6 responden (12\%) menyatakan netral, 34 responden $(68 \%)$ menyatakan setuju, dan 9 responden (18\%) menyatakan sangat setuju. Dari pernyataan mengelola pendapatan usaha dengan baik, tidak ada responden $(0 \%)$ yang menyatakan sangat tidak setuju, tidak ada responden $(0 \%)$ menyatakan tidak setuju, 8 responden (16\%) menyatakan netral, 32 responden (64\%) menyatakan setuju, dan 10 responden (20\%) menyatakan sangat setuju. Dari pernyataan menghadapi resiko pasar, tidak ada responden $(0 \%)$ yang menyatakan sangat tidak setuju, tidak ada responden $(0 \%)$ menyatakan tidak setuju, 11 responden (22\%) menyatakan netral, 34 responden (68\%) menyatakan setuju, dan 5 responden $(10 \%)$ menyatakan sangat setuju.

Amrizal

Putra

JURNAL EKONOMI SYARIAH INDONESIA, Volume V, No.1 Juni 2015 


\section{Faktor Kemampuan Membayar sebagai Variable X3}

Faktor kemampuan membayar merupakan faktor-faktor yang berkaitan dengan kemampuan seorang nasabah dalam membayar angsuran pembiayaan yang diberikan bank. Indikatornya terdiri dari ketepatan waktu dalam membayar, keuntungan untuk membayar angsuran, nominal angsuran dan pemberian pembiayaan lebih dari satu kali. Tanggapan dari nasabah BMT Artha Barokah Yogyakarta terhadap faktor kemampuan membayar adalah sebagai berikut:

Tabel 11. Distribusi Pendapat Responden Terhadap Kemampuan Membayar (X3)

\begin{tabular}{|c|c|c|c|c|c|c|c|c|c|c|c|c|}
\hline \multirow[t]{2}{*}{ BUTIR } & \multicolumn{2}{|c|}{$\begin{array}{c}\text { Sangat Tidak } \\
\text { Setuju }\end{array}$} & \multicolumn{2}{|c|}{$\begin{array}{l}\text { Tidak } \\
\text { Setuju }\end{array}$} & \multicolumn{2}{|c|}{ Netral } & \multicolumn{2}{|c|}{ Setuju } & \multicolumn{2}{|c|}{$\begin{array}{l}\text { Sangat } \\
\text { Setuju }\end{array}$} & \multirow{2}{*}{$\begin{array}{c}\text { Total } \\
\mathrm{F} \\
\mathrm{F} \\
\end{array}$} & \multirow{2}{*}{$\begin{array}{c}\text { Total } \\
\% \\
\% \\
\end{array}$} \\
\hline & $\mathrm{F}$ & $\%$ & $\mathrm{~F}$ & $\%$ & $\mathrm{~F}$ & $\%$ & $\mathrm{~F}$ & $\%$ & $\mathrm{~F}$ & $\%$ & & \\
\hline 1 & 0 & 0 & 1 & 2 & 4 & 8 & 30 & 60 & 15 & 30 & 50 & 100 \\
\hline 2 & 0 & 0 & 0 & 0 & 5 & 10 & 35 & 70 & 10 & 20 & 50 & 100 \\
\hline 3 & 0 & 0 & 2 & 4 & 5 & 10 & 30 & 60 & 13 & 26 & 50 & 100 \\
\hline 4 & 0 & 0 & 10 & 20 & 2 & 4 & 25 & 50 & 13 & 26 & 50 & 100 \\
\hline
\end{tabular}

Berdasarkan tabel 11 dapat dilihat bahwa dari pernyataan ketepatan waktu dalam membayar, tidak ada responden $(0 \%)$ yang menyatakan sangat tidak setuju, 1 responden ( $2 \%)$ menyatakan tidak setuju, 4 responden $(8 \%)$ menyatakan netral, 30 responden $(60 \%)$ menyatakan setuju, dan 15 responden $(30 \%)$ menyatakan sangat setuju. Dari pernyataan keuntungan untuk membayar angsuran, tidak ada responden $(0 \%)$ yang menyatakan sangat tidak setuju, tidak ada responden $(0 \%)$ menyatakan tidak setuju, 5 responden $(10 \%)$ menyatakan netral, 35 responden (70\%) menyatakan setuju, dan 10 responden (20\%) menyatakan sangat setuju. Dari pernyataan mengelola pendapatan usaha dengan baik, tidak ada responden $(0 \%)$ yang menyatakan sangat tidak setuju, 2 responden (4\%) menyatakan tidak setuju, 5 responden (10\%) menyatakan netral, 30 responden (60\%) menyatakan setuju, dan 13 responden (26\%) menyatakan sangat setuju. Dari pernyataan pemberian pembiayaan lebih dari satu kali, tidak ada responden $(0 \%)$ yang menyatakan sangat tidak setuju, 10 responden (20\%) menyatakan tidak setuju, 2 responden (4\%) menyatakan netral, 25 responden (50\%) menyatakan setuju, dan 13 responden (26\%) menyatakan sangat setuju.

\section{Faktor Anggaran Pendapatan sebagai Variabel Y}

Faktor anggaran pendapatan merupakan rencana penggunaan pendapatan yang diperoleh dari suatu usaha. Indikatornya terdiri dari modal usaha, pendapatan yang disisihkan, memenuhi tujuan yang diharapkan dan keuntungan anggaran pendapatan. Tanggapan dari nasabah BMT Artha Barokah Yogyakarta terhadap faktor anggaran pendapatan adalah sebagai berikut:

Tabel 12. Distribusi Pendapat Responden Terhadap Anggaran Pendapatan (Y)

Pengaruh

\begin{tabular}{ccccccccccccc}
\hline \multirow{3}{*}{$\begin{array}{c}\text { Tidangat } \\
\text { Tidak Setuju }\end{array}$} & \multicolumn{2}{c}{$\begin{array}{c}\text { Tidak } \\
\text { Setuju }\end{array}$} & Netral & Setuju & \multicolumn{3}{c}{$\begin{array}{c}\text { Sangat } \\
\text { Setuju }\end{array}$} & $\begin{array}{c}\text { Total } \\
\text { F }\end{array}$ & $\begin{array}{c}\text { Total } \\
\%\end{array}$ \\
\hline & F & $\%$ & F & $\%$ & F & $\%$ & F & $\%$ & F & $\%$ & F & $\%$ \\
\hline 1 & 0 & 0 & 1 & 2 & 0 & 0 & 43 & 86 & 6 & 12 & 50 & 100 \\
2 & 0 & 0 & 4 & 8 & 2 & 4 & 33 & 66 & 11 & 22 & 50 & 100 \\
3 & 0 & 0 & 3 & 6 & 9 & 18 & 34 & 68 & 4 & 8 & 50 & 100 \\
4 & 0 & 0 & 0 & 0 & 2 & 4 & 42 & 82 & 6 & 12 & 50 & 100 \\
\hline
\end{tabular}


Berdasarkan tabel 12 dapat dilihat bahwa:

Dari pernyataan modal usaha, tidak ada responden $(0 \%)$ yang menyatakan sangat tidak setuju, 1 responden $(2 \%)$ menyatakan tidak setuju, tidak ada responden $(0 \%)$ menyatakan netral, 43 responden $(86 \%)$ menyatakan setuju, dan 6 responden (12\%) menyatakan sangat setuju.

Dari pernyataan pendapatan yang disisihkan, tidak ada responden $(0 \%)$ yang menyatakan sangat tidak setuju, 4 responden $(8 \%)$ menyatakan tidak setuju, 2 responden ( $4 \%$ ) menyatakan netral, 33 responden $(66 \%)$ menyatakan setuju, dan 11 responden (22\%) menyatakan sangat setuju.

Dari pernyataan memenuhi tujuan yang diharapkan, tidak ada responden $(0 \%)$ yang menyatakan sangat tidak setuju, 3 responden $(6 \%)$ menyatakan tidak setuju, 9 responden (18\%) menyatakan netral, 34 responden $(68 \%)$ menyatakan setuju, dan 4 responden $(8 \%)$ menyatakan sangat setuju.

Dari pernyataan keuntungan anggaran pendapatan, tidak ada responden $(0 \%)$ yang menyatakan sangat tidak setuju, tidak ada responden $(0 \%)$ menyatakan tidak setuju, 2 responden (4\%) menyatakan netral, 42 responden $(84 \%)$ menyatakan setuju, dan 6 responden $(12 \%)$ menyatakan sangat setuju.

\section{Analisis Kuantitatif}

\section{Analisis Regresi Berganda}

Analisis regresi berganda digunakan untuk mengetahui seberapa besar pengaruh variabel bebas yang terdiri dari variabel nasabah, bank, dan eksternal terhadap variabel terikat yaitu pembiayaan bermasalah pada BMT Artha Barokah Yogyakarta.

Persamaan regresinya adalah sebagai berikut:

$$
\mathrm{Y}=\mathbf{a}+b_{1} X_{1}+b_{2} X_{2}+b_{3} X_{3}+\mathbf{e}
$$

Analisis regresi linier berganda dalam penelitian ini menggunakan program SPSS versi 16.0 yang dapat dilihat pada tabel berikut ini:

Tabel 13. Analisis Regresi Linier Berganda Coefficients $^{\mathrm{a}}$

\begin{tabular}{|c|c|c|c|c|c|c|}
\hline \multirow{2}{*}{\multicolumn{2}{|c|}{ Model }} & \multicolumn{2}{|c|}{$\begin{array}{c}\text { Unstandardized } \\
\text { Coefficients }\end{array}$} & \multirow{2}{*}{$\begin{array}{c}\begin{array}{c}\text { Standardized } \\
\text { Coefficients }\end{array} \\
\text { Beta }\end{array}$} & \multirow[b]{2}{*}{$\mathrm{T}$} & \multirow[b]{2}{*}{ Sig. } \\
\hline & & $\mathrm{B}$ & Std. Error & & & \\
\hline 1 & (Constant) & .879 & 2.997 & & .293 & .771 \\
\hline & Pro & .216 & .116 & 211 & 1.862 & .069 \\
\hline & KinerjaNasabah & .427 & .120 & .435 & 3.566 & .001 \\
\hline & Kemampuan Membayar & .287 & .092 & .374 & 3.123 & .003 \\
\hline
\end{tabular}

a. Dependent Variable: AnggaranPendapatan

Sumber: Hasil pengolahan data (kuesioner) dengan SPSS 14.

Berdasarkan hasil pengolahan data seperti terlihat dalam tabel pada kolom kedua (Unstandardized coefesients) bagian B pada baris pertama diperoleh model persamaan regresi linier bergandanya adalah sebagai berikut:

$$
Y=0,879+0,216 X_{1}+0,427 X_{2}+0,287 X_{3}+e
$$

Amrizal

Putra

JURNAL EKONOMI SYARIAH INDONESIA, Volume V, No.1 Juni 2015 
Dimana:

$\begin{array}{ll}\mathrm{Y} & =\text { Anggaran Pendapatan } \\ \mathrm{X}_{1} & =\text { Faktor Prospek Usaha } \\ \mathrm{X}_{2} & =\text { Faktor Kinerja Nasabah } \\ \mathrm{X}_{3} & =\text { Faktor Kemampuan Membayar } \\ \mathrm{a} & =\text { Nilai Konstanta } \\ \mathrm{b} & =\text { Koefesien Regresi } \\ \mathrm{e} & =\text { Standar Eror }\end{array}$

\section{Uji thitung (Uji Secara Parsial)}

Thitung bertujuan untuk mengetahuibesarnya pengaruh masing-masing variabel independen secara individual (parsial) terhadap variabel dependen.

Hasil uji ini pada output SPSS dapat dilihat pada tabel Coefficients.

Kriteria pengujinnya sebagai berikut:

Ho : bi $=0$, artinya tidak terdapat pengaruh $\mathrm{Xi}$ terhadap Pembiayaan Bermasalah.

Ho: bi $\neq 0$, artinya terdapat pengaruh Xi terhadap Pembiayaan Bermasalah.

Dengan kriteria pengambilan keputusan:

Ho diterima jika thitung $<$ ttabelpada $a=5 \%$

Hi diterima jika thitung $>$ ttabelpada $a=5 \%$

Jika probabilitasnya $>0,05$ maka Ho diterima

Jika probabilitasnya $<0,05$ maka Ho ditolak

Nilai t diperoleh dengan menggunakan bantuan program SPSS versi 16.0 seperti terlihat pada tabel 14 berikut ini:

Tabel 14. Hasil Uji thitung Coefficients $^{\mathrm{a}}$

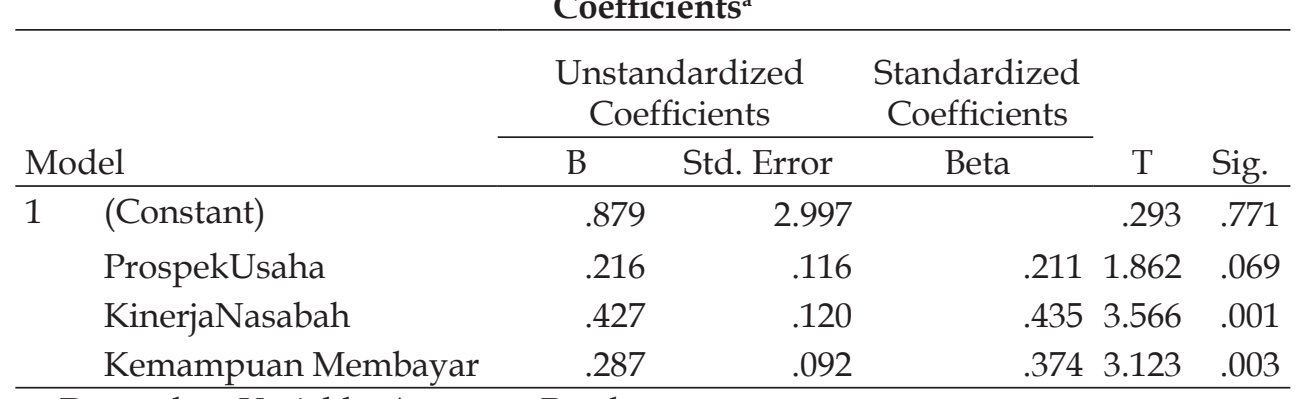

a. Dependent Variable: AnggaranPendapatan

Sumber: Hasil pengolahan data (kuesioner) dengan SPSS 14.0, 2010

Pada tabel 4.14 dapat diketahui bahwa nilai thitung untuk faktor prospek usaha (X1) adalah 1,862 ; faktor kinerja nasabah (X2) adalah 3,566 ; faktor kemampuan membayar (X3) adalah 3,123. Berdasarkan kriteria uji hipotesis maka dapat disimpulkan:

\section{Faktor Prospek Usaha (X1)}

Pengaruh Kualitas

Nilai thitung dari faktor ini adalah 1,862 dengan tingkat signifikan 0,069.

Nilai ttabel pada $\alpha=5 \%$, dengan derajat kebebasan $(\mathrm{df})=48$ adalah 1,677. berdasarkan kriteria uji hipotesis yaitu thitung > ttabelmaka Ho ditolak dan Hi diterima, maka dapat dinyatakan bahwa dengan nilai 1,862 >1,677. dan dinyatakan tidak signifikan karena 0,069 > 0,05 sehingga hipotesis ditolak. 
Artinya bahwa pengaruh faktor prospek usaha terhadap anggaran pendapatan adalah positif dan tidak signifikan.

\section{Faktor Kinerja Nasabah (X2)}

Nilai thitung dari faktor ini adalah 3,566 dengan tingkat signifikan 0,001.

Nilai ttabel pada $\alpha=5 \%$, dengan derajat kebebasan $(\mathrm{df})=48$ adalah 1,677. berdasarkan kriteria uji hipotesis yaitu thitung > ttabelmaka Ho ditolak dan Hi diterima, maka dapat dinyatakan bahwa dengan nilai 3,566 >1,677. dan dinyatakan signifikan karena 0,001 $<0,05$ sehingga hipotesis diterima. Artinya bahwa pengaruh faktor kinerja nasabah terhadap anggaran pendapatan adalah positif dan signifikan.

\section{Faktor Kemampuan Membayar (X3)}

Nilai thitung dari faktor ini adalah 3,123 dengan tingkat signifikan 0,003.

Nilai ttabel pada $\alpha=5 \%$, dengan derajat kebebasan $(\mathrm{df})=48$ adalah 1.677 . berdasarkan kriteria uji hipotesis yaitu thitung < ttabel maka Ho diterima dan Hi ditolak, maka dapat dinyatakan bahwa dengan nilai 3,123 > 1,677. dan dinyatakan signifikan karena 0,003 $<0,05$ sehingga hipotesis dterima. Artinya bahwa pengaruh faktor kemampuan membayar terhadap anggaran pendapatan adalah positif dan signifikan.

\section{Uji Simultan dengan F statistik (ANOVA)}

Uji statistik F pada dasarnya menunjukkan apakah semua variabel independen atau bebas yang dimasukkan dalam model mempunyai pengaruh secara bersama-sama terhadap variabel dependen (terikat).

Hasil uji F dengan SPSS 16 for windows adalah sebagai berikut:

Tabel 15. Uji statistik F

ANOVA $^{\mathrm{b}}$

\begin{tabular}{llrrrrr}
\hline \multirow{2}{*}{ Model } & & Sum of & & & & \\
\hline \multirow{2}{*}{1} & Squares & Df & Mean Square & F & \multicolumn{1}{l}{ Sig. } \\
\cline { 2 - 7 } & Regression & 46.627 & 3 & 15.542 & 12.058 & $.000^{\mathrm{a}}$ \\
\cline { 2 - 7 } & Residual & 59.293 & 46 & 1.289 & & \\
\cline { 2 - 6 } & 105.920 & 49 & & & \\
\hline
\end{tabular}

a. Predictors: (Constant), KemampuanMembayar, ProspekUsaha, KinerjaNasabah

b. Dependent Variable: AnggaranPendapatan

Pada tabel di atas dapat dilihat bahwa hasil signifikan uji F untuk Anggaran Pendapatan sebesar 0,000. Hasil uji tersebut berada di bawah nilai alpha 0,05, kemudian nilai Fhitung sebesar 12,058 sedangkan nilai Ftabel sebesar 1,677 (Fhitung $>$ Ftabel) sehingga dapat disimpulkan bahwa terdapat pengaruh signifikan secara simultan antara variabel independen (prospek usaha, kinerja nasabah, dan kemampuan membayar) terhadap anggaran pendapatan.

\section{Uji determinan $\left(R^{2}\right)$}

Nilai $R^{2}$ mempunyai interval dari 0 sampai $1\left(0 \leq R^{2} \leq 1\right)$, semakin besar $R^{2}$ Amrizal Putra 0 maka variabel independen secara serentak tidak dapat menjelaskan variabilitas dari variabel dependen. 


\section{Tabel 16}

Model Summary ${ }^{b}$

\begin{tabular}{|c|c|c|c|c|c|}
\hline Model & $\mathrm{R}$ & R Square & $\begin{array}{c}\text { Adjusted R } \\
\text { Square }\end{array}$ & $\begin{array}{l}\text { Std. Error of } \\
\text { the Estimate }\end{array}$ & Durbin-Watson \\
\hline 1 & $.663^{a}$ & .440 & .404 & 1.13533 & 1.952 \\
\hline
\end{tabular}

Dari hasil statistik diperoleh koefesien determinasi $\mathrm{R}^{2}=0,440$ yang berarti $44 \%$ dari variasi variabel terikat (dependen) dapat dijelaskan oleh variasi variabel bebasnya (independen), sedangkan 56\% lainnya dijelaskan oleh variasi variabel lain di luar penelitian ini.

\section{Uji Normalitas}

Uji normalitas bertujuan untuk menguji apakah dalam model regresi variabel residual (dependen dan independen) memiliki distribusi normal atau tidak. Model regresi yang baik adalah distribusi data normal atau mendekati normal (Ghazali, 2001). Hal ini dapat diketahui dengan melihat penyebaran data (titik-titik) pada sumbu diagonal dari grafik. Dasar pengambilan keputusan tersebut adalah dengan dua cara yaitu dengan analisis dan uji statistik.

Uji statistik yang digunakan untuk menguji ormalitas residual adalah uji statistik non-parametrik, yaitu uji kolomogorov-smirnov (K-S).

Tabel 17

One-Sample Kolmogorov-Smirnov Test

\begin{tabular}{llrrrr}
\hline & & $\begin{array}{c}\text { Prospek } \\
\text { Usaha }\end{array}$ & $\begin{array}{c}\text { Kinerja } \\
\text { Nasabah }\end{array}$ & $\begin{array}{c}\text { Kemampuan } \\
\text { Membayar }\end{array}$ & $\begin{array}{c}\text { Anggaran } \\
\text { Pendapatan }\end{array}$ \\
\hline $\mathrm{N}$ & & 50 & 50 & 50 & 50 \\
\hline Normal & Mean & 16.1000 & 16.2800 & 16.1800 & 15.9600 \\
Parameters & Std. & 1.43214 & 1.49884 & 1.91333 & 1.47025 \\
& Deviation & .368 & .254 & .197 & .271 \\
Most & Absolute & .368 & .254 & .197 & .269 \\
Extreme & Positive & -.232 & -.206 & -.103 & -.271 \\
Differences & Negative & 2.601 & 1.797 & 1.396 & 1.915 \\
Kolmogorov-Smirnov Z & .000 & .003 & .040 & .001 \\
Asymp. Sig. (2-tailed) & & & & \\
\hline
\end{tabular}

a. Test distribution is Normal.

Dari tabel hasil uji K-S di atas, dengan nilai $a=0,05$. Untuk anggaran pendapatan $(\mathrm{Y})$ memberikan nilai 1,915 dengan probabilitas 0,001, untuk factor prospek usaha (X1) memberikan nilai 2,601 dengan probabilitas 0,000, untuk factor kinerja nasabah (X2) memberikan nilai 1,797 dengan probabilitas 0,003, dan untuk factor kemampuan membayar (X3) memberikan nilai

Pengaruh 1,396 dengan probabilitas 0,40, terlihat bahwa semua variabel independen Kualitas mempunyai nilai Asymp. Sig. (2-Tailed)> 0,05, yang artinya bahwa data residual berdistribusi normal. 


\section{Uji autokorelasi}

Uji autokorelasi bertujuan untuk menguji, apakah dalam model regresi linier ada kolerasi antara kesalahan pengganggu pada periode $t$ dengan kesalahan pengganggu pada periode $\mathrm{t}-1$ (sebelumnya). Model regresi yang baik adalah model regresi yang bebas dari autokorelasi.Untuk mendeteksi gejala autokorelasi dengan menggunakan DW (Durbin-Watson).Nilai DurbinWatson (DW) digunakan sebagai prosedur formal untuk menguji keberadaan autokorelasi. Pedoman uji DW adalah:

Tabel 18. Dasar Pengambilan Keputusan Durbin-Watson

\begin{tabular}{cc}
\hline Hipotesis Nol & Jika \\
\hline Tidak ada otokorelasi positif & $0<\mathrm{d}<\mathrm{dl}$ \\
Tidak ada otokorelasi positif & $\mathrm{Dl}<\mathrm{d}<\mathrm{du}$ \\
Tidak ada otokorelasi negatif & $4-\mathrm{du}<\mathrm{d}<4$ \\
Tidak ada otokorelasi negatif & $4-\mathrm{du}<\mathrm{d}<4-\mathrm{dl}$ \\
Tidak ada otokorelasi positif & $\mathrm{Du}<\mathrm{d}<4-\mathrm{du}$ \\
atau negatif & \\
\hline
\end{tabular}

Tabel 19. Hasil Uji Autokorelasi dengan Uji Durbin-Watson Model Summary ${ }^{\text {b }}$

\begin{tabular}{lcrrrr}
\hline Model & $\mathrm{R}$ & R Square & $\begin{array}{c}\text { Adjusted R } \\
\text { Square }\end{array}$ & $\begin{array}{c}\text { Std. Error of the } \\
\text { Estimate }\end{array}$ & $\begin{array}{c}\text { Durbin- } \\
\text { Watson }\end{array}$ \\
\hline 1 & $.663^{\mathrm{a}}$ & .440 & .404 & 1.13533 & 1.952 \\
\hline
\end{tabular}

a. Predictors: (Constant), KemampuanMembayar, ProspekUsaha,

KinerjaNasabah

b. Dependent Variable: AnggaranPendapatan

\section{Uji Multikolinieritas}

Uji multikolinieritas bertujuan untuk menguji apakah dalam model regresi ditemukan adanya korelasi antara variabel bebas. Model regresi yang baik seharusnya tidak terjadi korelasi diantara variabel independen. Multikolinieritas sering diduga ketika nilai $\mathrm{R}^{2}$ tinggi namun semua nilai koefesien regresi tidak signifikan. Untuk mendeteksi multikolinieritas dengan menganalisis matrik korelasi antar variabel independen dan perhitungan nilai Tolerance dan VIF (Variance Inflation Factors). Nilai cut off yang umum dipakai untuk menunjukkan adanya multikolinieritas adalah Tolerance $<0,10$.

Tabel 20. Hasil Uji Multikolinieritas dengan Colliniearity Statistics Coefficients $^{\mathrm{a}}$

\begin{tabular}{|c|c|c|c|c|c|c|c|}
\hline \multirow[b]{2}{*}{ Model } & \multicolumn{2}{|c|}{$\begin{array}{c}\text { Unstandardized } \\
\text { Coefficients }\end{array}$} & $\begin{array}{l}\text { Standardized } \\
\text { Coefficients }\end{array}$ & \multirow[b]{2}{*}{$\mathrm{T}$} & \multirow[b]{2}{*}{ Sig. } & \multicolumn{2}{|c|}{$\begin{array}{c}\text { Collinearity } \\
\text { Statistics }\end{array}$} \\
\hline & B & $\begin{array}{l}\text { Std. } \\
\text { Error }\end{array}$ & Beta & & & $\begin{array}{l}\text { Tole- } \\
\text { rance }\end{array}$ & VIF \\
\hline 1 (Constant) & .879 & 2.997 & & .293 & .771 & & \\
\hline ProspekUsaha & .216 & .116 & .211 & 1.862 & .069 & .949 & 1.053 \\
\hline KinerjaNasabah & .427 & .120 & .435 & 3.566 & .001 & .818 & 1.222 \\
\hline $\begin{array}{l}\text { Kemampuan } \\
\text { Membayar }\end{array}$ & .287 & .092 & .374 & 3.123 & .003 & .849 & 1.178 \\
\hline
\end{tabular}

\section{Amrizal \\ Putra}

a. Dependent Variable: AnggaranPendapatan 
Dari uji multikolinieritas di atas, untuk semua variabel independen diperoleh hasil tidak ada yang memiliki nilai Tolerance kurang dari 0,1 dan nilai VIF berada dibawah 10, yaitu nilai factor kemampuan membayar memiliki nilai Tolerance 0,949 dan VIF 1,053, factor kinerja nasabah memiliki nilai Tolerance 0,818 dan VIF 1,222, dan factor kemampuan membayar memiliki nilai Tolerance 0,849 dan VIF 1,178. Maka dapat disimpulkan bahwa pada model regresi tidak terdapat gejala multikolinieritas.

\section{DAFTAR PUSTAKA}

Agustina, 2010, "Analisis Kualitas Pembiayaan dan Pengaruhnya Terhadap Efektifitas Pendapatan Pada PT. BPR SYARIAH PNM AL-MA'SOEM BANDUNG, Skripsi UNIKOM, Bandung

Al-Qur'an dan Terjemahan

Badudu, J.S. 2005, Ejaan Bahasa Indonesia yang Disempurnakan, Bandung: CV Nawaputra.

Dajan, Anto. 1986, Pengantar Metode Statistik, LP3ES, Jakarta.

Dokumentasi :

Dokumentasi KJKS-BMT Artha Barokah Yogyakarta.

Kasmir dan Jafkar, Studi Kelayakan Bisnis (Jakarta: Prenada Media,2003).

Muhammad. 2005. Manajemen Bank Syariah, (UPP) AMPYKPN, Yogyakarta.

Niswonger, dkk. 1999, Prinsip-Prinsip Akuntansi, Jilid 1, Edisi 19, Erlangga, Jakarta.

Siagian, Sondang P. 2001, Definisi Efektifitas, PT Bumi aksara, Jakarta.

Sofyan Syafri Harahap. 2002, Akuntansi Aktiva Tetap, Bumi Aksara, Jakarta.

Sugiyono. 2010. Metode Penelitian Pendidikan, Alfabet, Bandung.

Suharsimi. 2002. Prosedur Penelitian Suatu Pendekatan, Rineka Cipta, Jakarta.

Supardi, 2005. Metodologi Penelitian Ekonomi dan Bisnis, UII Press, Yogyakarta.

Umar Husein, 2005. Metodologi Penelitian Untuk Skripsi Dan Tesis Bisnis, PT Rajagrafindo Persada, Jakarta.

www.bi.go.id

Zainul Arifin, 2006. Dasar-Dasar Manajemen Bank Syariah, Cet 4 ,Pustaka Alvabet, Jakarta.

Pengaruh

Kualitas 